\title{
PENTINGYA EVALUASI PROGRAM DI INSTITUSI PENDIDIKAN: Sebuah Pengantar, Pengertian, Tujuan dan Manfaat ${ }^{1}$
}

\author{
Ashiong P. Munthe \\ Ashiong.munthe@uph.edu \\ Fakultas Ilmu Pendidikan - Universitas Pelita Harapan-Tangerang
}

\begin{abstract}
ABSTRAK
Evaluasi program hadir untuk memberikan masukan, kajian dan pertimbangan dalam menentukan apakah program layak untuk diteruskan atau dihentikan. Dengan kondisi demikian maka istilah evaluasi program menjadi sesuatu yang lumrah di lembaga pendidikan. Kajian ini untuk memberikan ulasan dan pengantar pentingnya sebuah evaluasi program di lembaga pendidikan. Kajian utam dalam tulisan ini adalah pengertian, tujuan dan maanfaat dari evaluasi. Tujuan adanya evaluasi program adalah memberikan pertimbangan sebelum adanya keputusan dari pemilik kebijakan. Manfaatnya adalah adanya keputusan yang tepat terhadap program yang sedang atau sudah dilaksanakan.
\end{abstract}

Kata kunci: Evaluasi program, Tujuan Evaluasi, Manfaat Evaluasi

\section{PENDAHULUAN}

Evaluasi yang sering dipahami selama ini dalam dunia pendidikan adalah terbatas pada penilaian saja. Penilaian ini dilakukan secara formatif dan sumatif. Ketika sudah dilakukan penilaian, dianggap sudah melakukan evaluasi. Pemahaman demikian tidaklah terlalu tepat. Pelaksanaan penilaian cenderung hanya melihat capaian tujuan pembelajaran saja. Pada hal, dalam proses pendidikan tersebut bukan hanya nilai yang dilihat, tetapi ada banyak faktor yang membuat berhasil atau tidaknya sebuah program. Penilaian hanya bagian kecil dari evaluasi. Evaluasi juga harus dipahami sebagai bagian dari supervisi. Evaluasi tidak hanya berurusan pada nilai yang diukur berdasarkan penyelesaian soal-soal, tetapi evaluasi program pendidikan akan mengkaji banyak faktor. Dengan demikian evaluasi program perlu diperkenalkan kepada seluruh pendidik, karena evaluasi sangat penting dalam pengembangan mutu pendidikan.

Menurut Gall, Gall and Borg (2007:559) "educational evaluation is the process of making judgments about the merit, value, or worth of educational ${ }^{1}$ Disampaikan dalam Workshop untuk Mahasiswa tentang Penelitian Metode Kuantitatif
dan Kualitatif di Fakultas Ilmu Pendidikan UPH, Karawaci, 16 dan 23 Juni 2015. 
programs”. Dapat diartikan bahwa evaluasi pendidikan adalah proses membuat penilaian tentang prestasi, nilai, atau nilai program pendidikan. Stufflebeam dan Shinkfield (2007:9) mengutip The Joint Committee's (1994) untuk mendefinisikan evaluasi "evaluation is the systematic assessment of the worth or merit of an object". Dalam buku The Program Evaluation Standards yang ditulis oleh Donald B. Yarbrough dkk (2010: xxiv). juga mengutip Joint Committee on Standards for Educational Evaluation (JCSEE, 1994) defined evaluation as the "systematic investigation of the worth or merit of an object". Dapat diartikan bahwa evaluasi sebagai "penyelidikan sistematis nilai atau manfaat dari sebuah objek". Lebih lanjut diuraikan Donald B. Yarbrough dkk (2010: xxiv) bahwa:

In the third edition, we expand the descriptive definition of program evaluation to include

- the systematic investigation of the quality of programs, projects, subprograms, subprojects, and/or any of their components or elements, together or singly

- for purposes of decision making, judgments, conclusions, findings, new knowledge, organizational development, and capacity building in response to the needs of identified stakeholders

- leading to improvement and/or accountability in the users programs and systems

- ultimately contributing to organizational or social value.

Menurut Wirawan (2011:7) mengatakan bahwa: "evaluasi sebagai riset untuk mengumpulkan, menganalisis, dan menyajikan informasi yang bermanfaat mengenai objek evaluasi, menilainya dan membandingkannya dengan indikator evaluasi dan hasilnya dipergunakan untuk mengambil keputusan mengenai objek evaluasi”.

Owen (2006:20) menjelaskan temuan-temuan evaluasi yang mencakup evidence, conclusions, judgments, and recommendations, yang dapat diartikan sebagai arti dari evaluasi tersebut: Findings encompass the following: Evidence. the data and other information which has been collected during the evaluation. Conclusions. the synthesis of data and information. these are the meanings those involved in the evaluation make though the synthesis of data. this involves evaluators in data display, data reduction and verification processes. Judgments. placing value on conclusions. Criteria are applied to the conclusions stating that the program is 'good' or 'bad', or that the results are 'positive', 'in the direction desired', or 'below expectations'. Recommendations. these are suggested courses of action, advice to policy-makers, program managers or providers about what to do in the light of the evidence and conclusions. 
Evaluasi program dapat disimpulkan sebagai suatu proses pencarian informasi, penemuan informasi dan penetapan informasi yang dipaparkan secara sistematis tentang perencanaan, nilai, tujuan, manfaat, efektifitas dan kesesuaian sesuatu dengan kriteria dan tujuan yang telah ditetapkan.

Berkaitan denan konsep penilaian dan evaluasi, seperti yang dikutip dari Widoyoko bahwa ada 3 istilah yang sering digunakan dalam evaluasi, yaitu tes, pengukuran, dan penilaian (test, measurement, and assessment). Mardapi dalam Widoyoko menguraikan tes sebagai salah satu cara untuk menaksir besarnya kemampuan seseorang secara tidak langsung, yaitu melalui respons seseorang terhadap stimulus atau pertanyaan. Lebih lanjut Mardapi dalam Widoyoko, mengatakan bahwa tes merupakan salah satu alat untuk melakukan pengukuran, yaitu alat untuk mengumpulkan informasi karakteristik suatu objek. Objek ini bisa berupa kemampuan peserta didik, sikap, minat, maupun motivasi. Respons peserta tes terhadap sejumlah pertanyaan menggambarkan kemampuan dalam bidang tertentu.

Pengukuran dinyatakan sebagai proses penetapan angka terhadap individu atau karakteristiknya menurut aturan tertentu (Ebel \& Frisbie. 1986: 14 dalam Widiyoko). Allen \& Yen dalam Widoyoko mendefinisikan pengukuran sebagai penetapan angka dengan cara yang sistematik untuk menyatakan keadaan individu. Widoyoko sendiri menyimpulkan pengukuran adalah kuantifikasi atau penetapan angka tentang karakteristik atau keadaan individu menurut aturan-aturan tertentu. Keadaan individu ini bisa berupa kemampuan kognitif, afektif dan psikomotor. Pengukuran memiliki konsep yang lebih luas dari pada tes. Kita dapat mengukur karakateristik suatu objek tanpa menggunakan tes, misalnya dengan pengamatan, skala rating atau cara lain untuk memperoleh informasi dalam bentuk kuantitatif.

Masih dalam Widoyoko penilaian (assessment) memiliki makna yang berbeda dengan evaluasi. The Task Group on Assessment and Testing (TGAT) mendeskripsikan asesmen sebagai semua cara yang digunakan untuk menilai unjuk kerja individu atau kelompok (Griffin \& Nix, 1991: 3). Popham (1995: 3) dalam Widoyoko mendefinisikan asesmen dalam konteks pendidikan sebagai sebuah usaha secara formal untuk menentukan status siswa berkenaan dengan berbagai kepentingan pendidikan.

Widoyoko menyatakan bahwa pengukuran, penilaian dan evaluasi bersifat hirarki. Evaluasi didahului dengan penilaian (assessment), sedangkan penilaian didahului dengan pengukuran. Pengukuran diartikan sebagai kegiatan membandingkan hasil pengamatan dengan kriteria, penilaian (assessment) merupakan kegiatan menafsirkan dan mendeskripsikan hasil pengukuran, sedangkan evaluasi merupakan penetapan nilai atau implikasi perilaku. 
Dari uraian di atas dapat disimpulkan bahwa tes, pengukuran, dan penilaian merupakan hal yang berbeda-beda dan bukan evaluasi itu sendiri melaikan bagian dari evaluasi. Tes merupakan salah satu alat untuk melakukan pengukuran terhadap objek tertentu. Pengukuran merupakan kuantifikasi atau penetapan angka tentang karakteristik atau keadaan individu menurut aturanaturan tertentu, sementara penilaian dapat diartikan sebagai kegiatan menafsirkan data hasil pengukuran.

Salah satu implementasi berbagai konsep tentang evaluasi adalah evaluasi tentang suatu program tertentu, khususnya program pendidikan; oleh karena itu perlu pemaparan tentang apa hakikat program itu. Pengertian program seperti yang dikutip oleh Owen dari Smith (1989:26) mengatakan bahwa: defines a program as: a set of planned activities directed toward bringing about specified change (s) in an identified and identifiable audience. This Suggests that a program has two essential components: a documented plan; and action consistent with the documentation contained in the plan. Dapat diartikan bahwa program adalah seperangkat kegiatan rencana yang diarahkan untuk membawa perubahan yang ditentukan dan diidentifikasi melalui audiens yang teridentifikasi. Dalam hal ini menunjukkan bahwa program memiliki dua komponen penting, yaitu rencana yang terdokumentasikan, dan tindakan yang konsisten dengan dokumentasi yang terkandung dalam rencana.

Menurut Donald B. Yarbrough dkk (2010: xxiv), bahwa: Programs as the systematic application of resources guided by logic, beliefs, and assumptions identifying human needs and factors related to them. Defined completely, a program is:

- a set of planned systematic activities

- using managed resources

- to achieve specified goals

- related to specific needs

- of specific, identified, participating human individuals or groups

- in specific contexts

- resulting in documentable outputs, outcomes, and impacts

- following assumed (explicit or implicit) systems of beliefs (diagnostic, causal, intervention, and implementation theories about how the program works)

- with specific, investigable costs and benefits.

Dapat diartikan program sebagai aplikasi sistematis dari sumber daya yang di dasarkan pada logika, keyakinan, dan asumsi identifikasi kebutuhan manusia dan faktor-faktor yang berhubungan dengan hal-hal yang sudah disebutkan. Program juga disebut sebagai hal yang termasuk di dalamnya 
serangkaian kegiatan sistematis yang direncanakan, adanya sumber daya yang dikelola, adanya sasaran target atau tujuan, adanya kebutuhan yang spesifik, diidentifikasi, adanya partisipasi individu atau kelompok, adanya konteks tertentu, menghasilkan output terdokumentasi, hasil, dan dampak, adanya sistem keyakinan yang terimplementasi dengan program kerja, dan memiliki manfaat.

Menurut Arikunto dan Jabar (2009:3) ada dua pengertian untuk istilah "program": Program dapat diartikan dalam arti khusus dan program dalam arti umum. Pengertian secara umum program adalah sebuah bentuk rencana yang akan dilakukan. "Program" apabila dikaitkan langsung dengan evaluasi program maka program diartikan sebagai unit atau kesatuan kegiatan yang merupakan realisasi atau implementasi dari kebijakan, berlangsung dalam proses yang berkesinambungan dan terjadi dalam suatu organisasi yang melibatkan sekelompok orang.

Lebih lanjut Arikunto mengatakan bahwa ada tiga pengertian penting dan perlu ditekankan dalam menentukan program, yaitu (1) realisasi atau implementasi suatu kebijakan, (2) terjadi dalam waktu relatif lama bukan kegiatan tunggal tetapi jamak berkesinambungan, dan (3) terjadi dalam organisasi yang melibatkan sekelompok orang. Program diartikan sebagai suatu unit atau kesatuan kegiatan yang dapat disebut sebagai sistem yang didalamnya terdapat rangkaian kegiatan yang dilakukan bukan hanya satu kali tetapi berkesinambungan.

Menurut Tayibnapis "program ialah segala sesuatu yang dicoba lakukan seseorang dengan harapan akan mendatangkan hasil atau pengaruh". Menurut Widoyoko "program diartikan sebagai serangkaian kegiatan yang direncanakan dengan saksama dan dalam pelaksanaannya berlansung dalam proses yang berkesinambungan, dan terjadi dalam suatu organisasi yang melibatkan banyak orang".

Program dapat diartikan sebagai suatu kegiatan atau aktifitas yang terencana dengan sistematis untuk diimplementasikan dalam kegiatan nyata secara berkelanjutan dalam organisasi serta melibatkan banyak orang di dalamnya.

\section{PEMBAHASAN}

\section{Perbedaan Evaluasi Program Dengan Penelitian Secara Umum}

Seperti uraian Blaine R. Worten dan James R. Sanders (1973:27-30) dalam Murzyanah (2011:1.2-1.3) mengatakan evaluasi program merupakan proses deskripsi, pengumpulan data dan penyampaian informasi kepada pengambil 
keputusan yang akan dipakai untuk pertimbangan apakah program perlu diperbaiki, dihentikan atau diteruskan. Adapun perbedaan evaluasi dengan penelitian umumnya terletak pada hasilnya. Hasil evaluasi adalah keputusan, sedangkan hasil penelitian adalah kesimpulan. Berikut ini akan diuraikan dalam bentuk tabel perbedaan antara evaluasi dengan penelitian secara umum.

\begin{tabular}{|c|c|c|}
\hline Aspek & Evaluasi & Penelitian \\
\hline Masala & Tergantung Klien/Kebutuhan & Tergantung minat peneliti \\
\hline Motif & $\begin{array}{l}\text { Pemecahan masalah } \\
\text { praktis/mencari penyelesaian } \\
\text { dalam permasalahan suatu } \\
\text { program }\end{array}$ & $\begin{array}{l}\text { Memenuhi keingin } \\
\text { tahuan/pengembangan ilmu }\end{array}$ \\
\hline Tujuan & Berorientasi kepada keputusan & Mendapatkan kesimpulan \\
\hline Deskripsi & $\begin{array}{l}\text { Mencari deskripsi aktivitas } \\
\text { khusus }\end{array}$ & $\begin{array}{l}\text { Mengembangkan teori, menuju } \\
\text { rumusan/teori }\end{array}$ \\
\hline Objek yang digarap & $\begin{array}{l}\text { Menilai keberhargaan atau } \\
\text { manfaat sesuatu penerapan } \\
\text { dalam masyarakat }\end{array}$ & Menguji pengembangan ilmu \\
\hline Generalisasi & $\begin{array}{l}\text { Tidak dapat digeneralisasi, } \\
\text { karena orang lain belum tentu } \\
\text { boleh tahu }\end{array}$ & $\begin{array}{l}\text { Dapat digeneralisasi, baik waktu } \\
\text { maupun letak geografis, dapat } \\
\text { dipublikasikan. }\end{array}$ \\
\hline Teknik investigasi & $\begin{array}{l}\text { Memahami metodologi } \\
\text { penelitian }\end{array}$ & $\begin{array}{l}\text { Memahami metodologi } \\
\text { penelitian }\end{array}$ \\
\hline $\begin{array}{l}\text { Kriteria penilaian } \\
\text { (mempertimbangka } \\
\text { n aktifitas) }\end{array}$ & $\begin{array}{ll}\text { - } & \text { Utility (kegunaan) } \\
\text { - } & \text { Feasiability (kelayakan/dapat } \\
& \text { dikerjakan) } \\
\text { - } & \text { Propriety (ketepatan) atau } \\
& \text { accuracy (keakuratan) }\end{array}$ & $\begin{array}{ll}\text { - } & \text { Validitas Internal } \\
\text { - } & \text { Validitas eksternal }\end{array}$ \\
\hline Klien/Pemakai & Kelompok tertentu & Siapa saja yang berminat \\
\hline Waktu & Terbatas & Tidak ketat (lebih longgar) \\
\hline
\end{tabular}

Sumber: Muzayanah (2011). Evaluasi Program Pendidikan. Jakarta: Prodi Teknologi Pendidikan UNJ

Merujuk pada Arikunto dan Jabar (2009:7) menyatakan bahwa evaluasi program dapat dikatakan sebagai salah satu bentuk penelitian, yaitu penelitian evaluatif. Oleh karena itu, dalam pembicaraan evaluasi program, pelaksana berpikir dan menentukan langkah-langkah sebagaimana melaksanakan penelitian. Perbedaan yang mencolok antara penelitian dengan evaluasi program adalah seperti uraian dalam tabel berikut ini: 


\begin{tabular}{|lll|}
\hline \multicolumn{2}{|c|}{ Penelitian } & \multicolumn{1}{c|}{ Evaluasi } \\
\hline 1 & $\begin{array}{l}\text { Ingin mengetahui gambaran } \\
\text { tentang sesuatu kemudian } \\
\text { hasilnya dideskripsikan }\end{array}$ & $\begin{array}{l}\text { Ingin mengetahui seberapa tinggi } \\
\text { mutu atau kondisi sesuatu sebagai } \\
\text { hasil dari pelaksanaan program. } \\
\end{array}$ \\
& $\begin{array}{l}\text { Setelah data terkumpul dibandingkan } \\
\text { dengan kriteria dan standar tertentu }\end{array}$ \\
\hline 2 & Dituntun oleh rumusan masalah & Ingin mengetahui tingkat \\
& karena ingin mengetahui & ketercapaian tujuan program dan \\
& jawaban dari hasil penelitian & mengetahui letak kekurangan dan \\
& & sebabnya \\
\hline
\end{tabular}

\section{Tujuan Evaluasi Program}

Arikunto dan Jabar (2009:18) mengatakan bahwa tujuan diadakannya evaluasi program adalah untuk mengetahui pencapaian tujuan program dengan langkah mengetahui keterlaksanaan kegiatan program. Ada tujuh elemen yang harus dilakukan menurut Brikerhoff (1986:ix) dalam Arikunto dan Jabar, untuk pelaksanaan evaluasi, yaitu: 1) penentuan fokus yang akan dievaluasi (focusing the evaluation), 2) penyusunan desain evaluasi (designing the evaluation), 3) pengumpulan informasi (collecting information), 4) analisis dan intepretasi informasi (analyzing and interpreting), 5) pembuatan laporang (reporting information), 6) pengelolaan evaluasi (managing evaluation), dan 7) evaluasi untuk evaluasi (evaluating evaluation).

Tujuan evaluasi program seperti yang duraikan oleh Roswati (2008:66-67) adalah sebagai berikut: 1) menjawab pertanyaan-pertanyaan tentang tindak lanjut suatu program di masa depan, 2) penundaan pengambilan keputusan, 3) penggeseran tanggung jawab, 4) pembenaran/justifikasi program, 5) memenuhi kebutuhan akreditasi, 6) laporan akutansi untuk pendanaan, 7) menjawab atas permintaan pemberi tugas, informasi yang diperlukan, 8) membantu staf mengembangkan program, 9) mempelajari dampak/akibat yang tidak sesuai dengan rencana, 10) mengadakan usaha perbaikan bagi program yang sedang berjalan, 11) menilai manfaat dari program yang sedang berjalan, 12) memberikan masukan bagi program baru.

\section{Manfaat Evaluasi Program}

Arikunto dan Jabar (2009:21) menyatakan bahwa evaluasi program pendidikan adalah supervisi pendidikan dalam pengertian khusus, tertuju pada lembaga secara keseluruhan. Supervisi sekolah yang diartikan sebagai evaluasi program dapat disama artikan dengan validasi lembaga dan akreditasi. Roswati 
(2008:66-67) memaparkan tentang manfaat dari evaluasi program: 1) memberikan masukan apakah suatu program dihentikan atau diteruskan, 2) memberitahukan prosedur mana yang perlu diperbaiki, 3) memberitahukan stategi, atau teknik yang perlu dihilangkan/diganti, 4) memberikan masukan apakah program yang sama dapat diterapkan di tempat lain, 5) memberikan masukan dana harus dialokasikan ke mana, 6) memberikan masukan apakah teori/pendekatan tentang program dapat diterima/ditolak.

\section{Cara Menentukan Program dapat Dievaluasi}

Menurut Jody L. Patrick, dkk (2003:173-198) ada tiga langkah untuk menentukan apakah suatu program dapat dievaluasi atau tidak: 1) mengklarifikasi teori dan model program yang diinginkan, 2) mengkaji implementasi program untuk menentukan apakah cocok dengan model atau teori program dan dapat mencapai tujuan program dengan tepat, 3) menggali pendekatan-pendekatan evaluasi yang berbeda untuk menentukan derajat dimana evaluasi tersebut memenuhi kebutuhan informasi stakeholder dan layak untuk diimplementasikan, 4) menyepakati prioritas-prioritas evaluasi dan penggunaan dari hasil evaluasi yang diharapkan.

\section{Hasil Evaluasi yang Tidak Tepat}

Ada kondisi bahwa suatu evaluasi tidak tepat, oleh karena itu perlu memperhatikan secara seksama agar hasil evaluasi tepat. Berikut ini seperti yang diuraikan oleh Jody L. Patrick dkk (2003). Adapun kondisi evaluasi tidak tepa adalah sebagai berikut ini:

\section{Evaluasi akan Menghasilkan Informasi yang Sepele (Trivial Information)}

Evaluasi hanya menghasilkan informasi danghkal dan tidak bermakna atau tidak berguna. Hal ini dapat disebabkan beberapa factor, yaitu alah satunya anggaran yang terlalu kecil sehingga tidak memungkinkan menjangkau subyek evaluasi sehingga informasi yang diperoleh sedikit. Merencanakan evaluasi tidak didasarkan pada teori dan model yang memada, sehingga hasil evaluasi tidak ada berkaitan dengan program yang dievaluasi. Durasi waktu waktu untuk penelitian terlalu sempit atau terburu-buru, sehingga evaluasi tidak mendalam.

\section{Ketika Hasil Evaluasi Tidak akan Digunakan}

Hasil evaluasi tidak akan digunakan karena faktor tertentu, apakahh adanya perubahan kebijakan atau kondisilainya sehingga tidak dapat menggunakan hasil evaluasi.

\section{Evaluasi Tidak Dapat Menghasilkan Sesuatu yang Berguna, Informasi Tidak Valid}

Hasil evaluasi tidak berguna atau informasi tidak valid. Faktor ini dapat disebabkan oleh keterbatasan sumber daya, lemahnya dukungan dan kerjasama, 
keterbatasan waktu, tugas-tugas evaluasi yang tidak logis, lemahnya akses terhadap data penting yang diperlukan. Bisa juga karena program yang akan dievaluasi terlanjur pailit.

\section{Evaluasi Dilakukan pada Tahap Awal Program}

Program baru berjalan atau belum berjalan karena masih dalam rencana sudah dilakukan evaluasi. Hal ini tidak akan menghasilkan data apa-apa.

\section{Kepatutan Evaluasi Diragukan}

Tujuan untuk melakukan evaluasi harus jelas dan tepat. Jika evaluator melakukann evaluasi dengan tepat dan patut, maka peluang melaksanakan evaluasi akan tinggi. Evaluator harus mempertimbangkan dan menghindari apelanggaran kode etik profesi. Kepatutan menjadi salah satu atribut etika evaluasi. Ada tiga hal yang harus diperhatikan dalam evaluasi, yaitu akurasi (accuracy) atau ketepatan (propriety), kelayakan (feasibility), dan manfaat (utility).

\section{Model-Model Evaluasi}

Model evaluasi program yang dikembangkan oleh para ahli ada banyak model. Model-model tersebut cenderung dikembangkan sesuai dengan tujuan pelaksanaan evaluasi tersebut. Di bawah ini akan diuraikan beberapa model evaluasi program yang dirancang oleh para ahli, diantaranya:

\section{CSE-UCLA Model}

CSE-UCLA model menurut Arikunto (2009:44) CSE-UCLA merupakan singkatan dari dua bagian, yaitu CSE dan UCLA. CSE adalah singkatan dari Center for the Study of Evaluation, sedangkan UCLA adalah singkatan dari University of California in Los Angeles. CSE-UCLA Evaluation Model menekankan pada lima tahap yang dilakukan, yaitu: perencanaan, pengembangan, implementasi, hasil dan dampak. Menurut Fernandes (1984) seperti yang dikutip oleh Arikunto menjelaskan bahwa model CSE-UCLA menjadi empat tahap, yaitu: (1) need assessment, (2) program planning, (3) formative evaluation, dan (4) summative evaluation.

\section{Model Brinkerhoff}

Seperti yang diuraikan oleh Widoyoko (2013: 187-189) bahwa model evaluasi Brinkerhoff dikembangkan oleh Brinkerhoff \& CS (1983). Dikemukakan bahwa ada tiga golongan evaluasi yang disusun berdasarkan penggabungan elemenelemen yang sama seperti evaluator-evaluator lainnya, namun dalam komposisi dan versi mereka sendiri. Golongan evaluasi tersebut adalah Fixed vs Emergent Evaluation Design, Formative vs Summative Evaluation dan Experimental and Quasi Experimental Design vs Natural/ Unotrusive. 


\section{Evaluasi Model CIPP}

Istilah CIPP adalah singkatan dari Context, Inputs, Processes, and Products. Seperti yang diuraikan oleh Stufflebeam dan Shinkfield (2007:326.) the CIPP model's core concepts are denoted by the acronym CIPP, which stands for evaluations of an entity's context, inputs, processes, and products.

Seperti yang dikutip dari www.businessballs.com, bahwa ada beberapa model evaluasi sebagai berikut ini:

1. Jack Phillips' Five Level ROI Model

2. Daniel Stufflebeam's CIPP Model (Context, Input, Process, Product)

3. Robert Stake's Responsive Evaluation Model

4. Robert Stake's Congruence-Contingency Model

5. Kaufman's Five Levels of Evaluation

6. CIRO (Context, Input, Reaction, Outcome)

7. PERT (Program Evaluation and Review Technique)

8. Alkins' UCLA Model

9. Michael Scriven's Goal-Free Evaluation Approach

10. Provus's Discrepancy Model

11. Eisner's Connoisseurship Evaluation Models

12. Illuminative Evaluation Model

13. Portraiture Model

14. and also the American Evaluation Association

Sumber: http://www.businessballs.com/kirkpatricklearningevaluationmodel.htm, diambil 14 Juni 2015

\section{Metode Penentuan Obyek Evaluasi}

Evaluasi program sebagai penelitian harus memiliki metode dalam menentukan objek evaluasi. Adapun pendekatan dasar yang dapat dilakukan dalam penentuan objek evaluasi seperti yang dikatakan oleh Fitzpatrick dkk (2003: 173198) adalah sebagai berikut, 1) Dokumen deskriptif. Perlu membaca dokumen yang berhubungan denga evaluasi untuk mendapat informasi yang sah, 2) Wawancara. Wawancara dapat dilakukan kepada beberapa individu yamg sudah paham atau mengetahui program yang akan dievaluasi, dan 3) observasi. Pengamatan secara langsung bagaimana proses implementasi program tersebut.

Ketiga metode tersebut harus saling mendukung satu sama lainnya. Jika ada perbedaan hasil antara pengamatan dengan temuan dalam dokumen, maka perlu dilakukan klarifikasi melalui wawancara. Atau sebaliknya, jika hasil wawancara dan analisis dokumen tidak sinkron dengan implementasi di lapangan, maka dapat diklarifikasi dari hasil pengamatan. Sehingga ketiga sudut pandang tersebut dapat saling melengkapi. 


\section{Pemangku kepentingan dalam Pelaksanaan Evaluasi}

Keterlibatan individu dalam program tentunya bukan hanya satu orang saja, melainkan ada banyak individu sebagai pemangku kepentingan terhadap hasil evaluasi. Setiap individu tersebut memiliki perannya masing-masing. Dalam proses evaluasi juga demikian, tidak hanya satu orang yang terlibat. Secara umum individu yang terlibat dalam kegiatan evaluasi seperti yang dikatakan Muzayanah (2011:4.1), antara lain, 1) sponsor (sponsors) atau komisi evaluasi sebagai penanggung jawab dan penyedia dana, 2) klien (client) yang meminta adanya evaluasi, 3) partisipan sebagai sumber informasi dalam evaluasi, 4) pihak-pihak terkait (stakeholders) sebagai orang yang berkepentingan dan langsung dipengaruhi oleh hasil evaluasi (seperti ketua yayasan, pemerintah, orangtua, murid), 5) audien (audiens) adalah orang yang mempunyai minat dan perhatian terhadap evaluasi dan memperoleh hasilnya (seperti sponsor, klien, partisipan, stakeholder), 6) evaluator adalah mereka yang melaksanakan evaluasi.

\section{Cakupan Evaluasi Program Pembelajaran}

Mengutip contoh yang diuraikan oleh Widoyoko dalam penerapan evaluasi program pembelajaran, sekurang-kurangnya ada tiga komponen yang perlu dijadikan obyek evaluasi, yaitu 1) desain program pembelajaran, 2) implementasi program dan 3) hasil yang dicapai.

\section{Desain program pembelajaran}

Pada desain program pembelajaran maka hal yang perlu untuk dievaluasi adalah kompetensi dasar yang akan dikembangkan, strategi pembelajaran yang akan diterapkan, isi program pembelajaran. Salah satu aspek dalam kompetensi dasar yang perlu dikaji adalah pencapaian kompetensi dasar, standar kompetensi maupun kompetensi lulusan.

Pada strategi pembelajaran ada beberapa kriteria yang dapat digunakan untuk menilai strategi pembelajaran yang direncanakan, yaitu antara lain: kesesuaian dengan kompetensi yang akan dikembangkan, kesesuaian dengan kondisi belajar mengajar yang diinginkan, dan kejelasan rumusan, terutama mencakup aktivitas guru maupun siswa dalam proses pembelajaran.

Isi program pembelajaran yang dimaksud adalah pengalaman belajar yang akan disiapkan oleh guru maupun yang harus diikuti siswa. Seperti: relevansi dengan kompetensi yang akan dikembangkan, relevansi dengan pengalaman murid dan lingkungan, kesesuaian dengan tingkat perkembangan siswa, kesesuaian dengan alokasi waktu yang tersedia, keauthentikan pengalaman dengan lingkungan hidup siswa.

\section{Implementasi program}

Widoyoko menguraikan bahwa implementasi program pembelajara perlu dijadikan obyek evaluasi, khususnya proses belajar dan pembelajaran 
yang berlangsung di dalam kelas. Widoyoko mengutip Nana Sudjana \& Ibrahim (2004: 230-232) menampilkan sejumlah kriteria yang dapat digunakan untuk mengevaluasi proses pembelajaran yaitu: konsistensi dengan kegiatan yang terdapat dalam program pembelajaran, keterlaksanaan oleh guru, keterlaksanaan dari segi siswa, perhatian yang diperlihatkan para siswa terhadap pembelajaran yang sedang berlangsung, keaktifan para siswa dalam proses belajar.

\section{Hasil Program Pembelajaran}

Menurut Widoyok bahwa komponen ketiga yang perlu dievaluasi adalah hasil yang dicapai dalam kegiatan pembelajaran. Hasil yang dicapai ini dapat mengacu pada pencapaian tujuan jangka pendek (ouput) maupun mengacu pada pencapaian tujuan jangka panjang (outcome).

Dengan melakukan evaluasi pembelajaran seperti yang diuraikan di atas, maka akan ada gambaran yang utuh mengenai program pembelajar yang sudah dilaksanakan. Dari hasil evaluasi tersebut, akan ditemukan hal-hal yang masih kurang dan hal-hal yang perlu dipertahankan dari program. Dengan demikian evaluasi program pembelajaran sangat memungkinkan untuk dilaksanakan di sekolah ataupun di lembaga pendidikan lainnya.

\section{Evaluator Internal dan Eksternal}

Evaluator yang akan melaksanakan evaluasi program bisa dari dua ssumber, yaitu evaluator eksternal dan evaluator internal. Setiap sumber evaluator pasti memiliki kelebihan dan kekurangannya sendiri. Dalam table ini akan diuraikan tentang kelebihan dan kekurangan dari setiap evaluator.

\begin{tabular}{|cll|}
\hline No & \multicolumn{1}{c|}{ Internal } & \multicolumn{1}{c|}{ Eksternal } \\
\hline 1 & $\begin{array}{l}\text { Sangat mengetahui seluk beluk } \\
\text { program. }\end{array}$ & Sukar mengetahui seluk beluk program \\
\hline 2 & Mudah mendapatkan data & Sukar mendapatkan data esensial \\
\hline 3 & Seringkali tidak objektif & Dapat objektif karen tidak berkepentingan \\
\hline 4 & $\begin{array}{l}\text { Dapat memberi informasi penting } \\
\text { yang kontekstual }\end{array}$ & Tidak Dapat \\
\hline
\end{tabular}

Sumber: Roswati (2008). Jurnal Pendidikan Penabur-No.11/Tahun ke-7/Desember 2008 


\section{SIMPULAN}

Evaluasi program diartikan sebagai proses pencarian informasi, penemuan informasi dan penetapan informasi yang dipaparkan secara sistematis tentang perencanaan, nilai, tujuan, manfaat, efektifitas dan kesesuaian sesuatu dengan kriteria dan tujuan yang telah ditetapkan. Tujuan evaluasi program adalah untuk memberikan rekomendasi sebagai bahan pertimbangan dalam menentukan keputusan atas program yang dilaksanakan. Manfaatnya adalah adanya keputusan yang tepat sesuai dengan hasil evaluasi.

Evaluasi program harusnya sesuatu yang familiar di lingkunan sekolah dan lembaga pemdidikan lainnya. Lembaga pendidikan sudah seharusnya mengadakan evaluasi rutin di setiap program yang dilaksanakannya. Evaluasi yang dimaksud bukan hanya sekedar penilaian, tetapi evaluasi program secara menyeluruh. Evaluasi tersebut berguna untuk menentukan apakah program layak diteruskan, direvisi atau menghentikan program karena dianggap sudah tidak bermanfaat. Evaluasi juga akan mengukur ketercapaian setiap program yang sudah dilaksanakan. Evaluasi bisa diterapkan di dalam proses pembelajaran dalam kelas, evaluasi kebijakan, evaluasi proses, evaluasi dampak, atau evaluasi untuk pengembangan.

Menurut Tayibnapis (2008:4), “evaluasi hendaknya membantu pengembangan, implementasi, kebutuhan suatu program, perbaikan program, pertanggungjawaban, seleksi, motivasi, menambah pengetahuan, dan dukungan dari mereka yang terlibat".

\section{DAFTAR PUSTAKA}

Alkin, Marvin C. 1969. Evaluation Theory Development, UCLA CSE Evaluation Comment, Center For The Study of Evaluation, Vol.2, No.1, University of California, Los Angeles.

Arikunto, Suharsimi dan Jabar, Cepi Safruddin Abdul. 2009. Evaluasi Program Pendidikan:Pedoman Teoretis Praktis bagi Mahasiswa dan Praktisi Pendidikan. Jakarta: Bumi Aksara.

Fitzpatrick, Jody, Christie, Christina dan Mark, Melvin M. 2009. Evaluation in Action: Interviews With Expert Evaluators. California: Sage Publications.

Gall, Meredith D., Gall, Joyce dan Borg, Walter R. 2007. Educational Research: An Introduction. New York: Pearson Education. 
Pentingnya Evaluasi Program di Institusi Pendidikan (Ashiong P.Munthe)

Kirkpatrick, Donald, L. 2015. Learning Evaluation Model. Available http://www.businessballs.com/ kirkpatricklearningevaluationmodel.htm, diambil 14 Juni 2015.

Kirkpatrick, Donald, L. dan Kirkpatrick, James D. 2006. Evaluating Training Programs: The Four Levels . San Francisco: Berrett-Koehler.

Muzayanah. 2011. Evaluasi Program Pendidikan. Jakarta: Prodi Teknologi Pendidikan UNJ.

Owen, John M. 2006. Program Evaluation: Forms and Appoaches. Crows Nest: Allen \& Unwin.

Roswati. 2008. Evaluasi Program/Proyek (Pengertian, Fungsi, Jenis, dan Format Usulan), Jurnal Pendidikan Penabur-No.11/Tahun ke-7/Desember 2008. http://www.bpkpenabur.or.id/files/Hal.\%206471\%20Evaluasi\%20Progra m.pdf. Diambil 12 Juni 2015.

Stufflebeam, Daniel L. dan Shinkfield, Anthony J. 2007. Evaluation Theory, Models, and Application. San Francisco: Jossey-Bass.

Tayibnapis, Farida Yusuf. 2008. Evaluasi Program dan Instrumen Evaluasi untuk Program Pendidikan dan Penelitian. Jakarta: Rineka Cipta.

Widoyoko, Eko Putro. 2015. Evaluasi Program Pembelajaran. Available on http://www.umpwr.ac.id/download/publikasiilmiah/Evaluasi\%20Progra m\%20Pembelajaran.pdf. Diambil 12 Juni 2015.

Widoyoko, Eko Putro. 2013. Evaluasi Program Pembelajaran:Panduan Praktis bagi Pendidik dan Calon Pendidik. Yogyakarta: Pustaka Pelajar.

Wirawan. 2011. Evaluasi: Teori, Model, Standar, Aplikasi dan Profesi. Jakarta: Rajagrafindo Persada.

Yarbrough, Donald B., et. al. 2010. Joint Committee on Standards for Educational Evaluation: The Program Standards: A Guide for Evaluators and Evaluation Users. California: Sage Publication. 